\title{
Health Risk Assessment of Heavy Metal Contaminated Sites in India
}

\author{
Neeraj Chuadhary ${ }^{1}$, Manish Jain ${ }^{2}$, V. P. Singh ${ }^{3}$, Prof. R. K. Srivastava ${ }^{4}$ \\ ${ }^{1}$ Student, Motilal Nehru National Institute of Technology Allahabad, U. P., India-211004. \\ ${ }^{2}$ Student, Motilal Nehru National Institute of Technology Allahabad, U. P., India-211004. \\ ${ }^{3}$ Asst. Prof., Motilal Nehru National Institute of Technology Allahabad, U. P., India-211004. \\ ${ }^{4}$ Professor, Motilal Nehru National Institute of Technology Allahabad, U. P., India-211004.
}

\begin{abstract}
Due to various health risks associated with contaminated sites, health risk assessment has gained a lot of attention among the researchers worldwide. Health risk analysis is also one of the elementary steps involved in the selection of a cleanup program for a site. In this paper, the non carcinogenic (as Hazard Index) and carcinogenic health risks are evaluated for the three contaminated sites located in different parts of India i.e. Balanagar industrial area (Hyderabad), Pali industrial area (Rajasthan) and Surat industrial area situated in south Gujarat, to identify the potential health risks to human involved with the exposure to the site. Analysis was made for three receptors (i.e., child, adult and industrial worker) by considering three types of exposure pathways (ingestion, inhalation and dermal contact). Results demonstrated site 1 to be highly contaminated as the induced risks were much higher than safe level. Site 2 was mainly polluted by $\mathrm{Cr}$ and $\mathrm{Pb}$ only. High carcinogenic risk was induced with the exposure to site 3 due to accumulation of high concentration of $\mathrm{Cr}$.
\end{abstract}

Keywords: Carcinogenic Risk, Hazard Index, Hazard Quotient, Non-Carcinogenic Risk.

\section{Introduction}

In the last few decades, millions of contaminated sites have been discovered all over the world. Most of the developed and developing countries are facing the problem of land scarcity, especially in urban areas, due to contamination. India is also one of them. Till date, there are a total of 557 sites identified as contaminated in India, with total area of about 175 million hectares. Also, huge number remains unidentified. Most of these sites reported are found in Uttar Pradesh (75), Punjab (61), Gujarat (54), Andhra Pradesh (46), Madhya Pradesh (38), National Capital Territory (32) and Rajasthan (21) [1]. As per the report of MoEF [1], most of the sites in India are contaminated with Chromium (160), Lead (104), Cadmium (50), Mercury (35) and Arsenic (20). Other heavy metals such as $\mathrm{Ba}, \mathrm{Co}, \mathrm{Cu}, \mathrm{Sr}, \mathrm{V}, \mathrm{Y}, \mathrm{Zn}$ etc. are also found in most of the sites. Some heavy metals like $\mathrm{Ca}, \mathrm{Mg}, \mathrm{Cu}, \mathrm{Zn}$ etc) are found important for human upto a regulatory limit. However excess will result in poisoning or toxicity, which is evident by certain reported medical symptoms that are clinically diagnosable [2, 3, 4 and 5]. Chromium generally occurs in two oxidation states, $\mathrm{Cr}(\mathrm{III})$ and $\mathrm{Cr}(\mathrm{VI}) . \mathrm{Cr}(\mathrm{III})$ is an essential nutrient for human in amounts of 50-200 $\mu \mathrm{g}$ /day. But even a small concentration of $\mathrm{Cr}(\mathrm{VI})$ is harmful for human. Exposure to $\mathrm{Cr}(\mathrm{III})$ and $\mathrm{Cr}(\mathrm{VI})$ compounds can be associated with allergic responses in sensitive individuals. Effects also include irritating respiratory effects, effects on stomach and blood, liver and kidney effects and increased risk of death from lung cancer [5, 6 and 7]. Unlike other heavy metals, Lead $(\mathrm{Pb})$, Cadmium $(\mathrm{Cd})$ and Mercury $(\mathrm{Hg})$ have no bio-importance in human biochemistry and physiology and consumption of even a small amount of concentration may be toxic. Adverse health effects of $\mathrm{Cd}$ exposure include primarily in the form of kidney damage but possibly also bone effects and fracture [5]. The symptoms of acute lead poisoning are headache, irritability, abdominal pain and various symptoms related to the nervous system. Children may be affected by behavioral disturbances, learning and concentration difficulties. In severe cases of lead encephalopathy, the affected person may suffer from acute psychosis, confusion and reduced consciousness. People who have been exposed to $\mathrm{Pb}$ for a long time may suffer from memory deterioration, prolonged reaction time and reduced ability to understand [8]. Long term exposure to Arsenic (As) is mainly related to increased risks of skin cancer, but also some other cancers, as well as other skin lesions such as hyperkeratosis and pigmentation changes. Occupational exposure to arsenic, primarily by inhalation, is sometimes associated with lung cancer [9]. Health risks associated with contaminated sites may be harmful enough to cause cancer, known as carcinogenic health risks otherwise they may be less harmful but still problematic, known as non-carcinogenic health risks. Due to all these associated health risks, health risk assessment of a contaminated site has gained a lot of attention among the researchers. A large number of researchers have worked to determine the concentration of various contaminants at different sites in India like Chhattisgarh [10], Hyderabad [11 
Health Risk Assessment of Heavy Metal Contaminated Sites in India

and 12], Kanpur [13, 14, 15, 16 and 17], Mumbai [18], Mysore [19 and 20], Patancheru [21], Pondicherry [22], Rajasthan [23], Ranga Reddy [24], Surat [25], Sivasagar and Dibrugarh [26], Tamil Nadu [27] and Thane [28]. Only few researchers have discussed the health risk associated to the contaminated sites in India. Singh et. al. [29] discussed the risk assessment of heavy metals associated with contaminated vegetables in Varanasi. The reclamation of contaminated sites with perspective of future reuse of land requires assessment of land post cleanup with two perspectives, one its restoration with respect to possible land use and second with respect to reduced health risks to acceptable limits. Therefore, choice of remediation technology has to be primarily compatible with both these requirements apart from other criteria. It is in this context that health risk assessment has become of prime importance for any land reclamation and reuse project. In this study, three sites were selected out of pre-identified 557 contaminated sites, each from Andhra Pradesh, Rajasthan and Gujarat. Work has been already done at Balanagar Industrial Area, Hyderabad [12]; Pali Industrial Area, Rajasthan [23] and Surat Industrial Area, Gujarat [25] to determine the extent and concentration of heavy metals. Results presented by these authors were used in this study for the assessment of carcinogenic and non-carcinogenic health risks to human. Aims of this study are to: (1) determine the potential health risks to human induced due to contamination by heavy metals (2) provide a basis for the selection of remediation process, (3) define an acceptable level of contaminant concentration on the site.

\section{Site Description}

Three contaminated sites were selected from different parts of India. Concentrations of heavy metals presented by various researchers were used for the study. Site 1 is Balanagar industrial area situated in the northwestern part of Hyderabad City, India [12]. Main industries causing the contamination in this site are: steel, chemical, automobiles, refineries and battery manufacturing. Site 2 is Pali industrial area, Pali district, Rajasthan, India which is also identified as polluted by Central Pollution Control Board (CPCB), New Delhi [23]. Around 300 industries exist in this area which includes chemical, dye, textile, paint and marble based industries. Site 3 is Surat industrial area situated in south Gujarat, India [25]. This site is also identified as polluted by Central Pollution Control Board (CPCB), New Delhi. There are large number of small scale and also several large and medium scale textile industries. Other industries that have come up in and around Surat include petrochemical, refinery, natural gas, cement, steel plant etc. Table 1 shows the heavy metal concentration present on each site.

Table 1: Heavy metal concentrations in soil

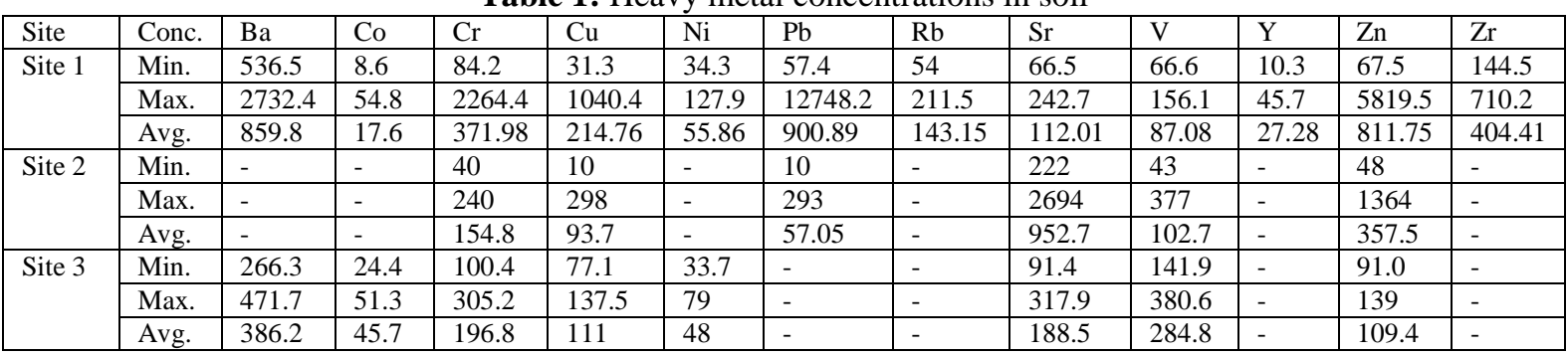

Table 2: Chronic Average Daily Demand (CADD) can be calculated by using the following formulas

\begin{tabular}{|c|c|c|c|}
\hline \multicolumn{3}{|c|}{ Chronic Average Daily Dose (CADD) } & \multirow[b]{2}{*}{ Reference } \\
\hline Ingestion & Inhalation & Dermal Contact & \\
\hline $\mathrm{C} \times \operatorname{lingR} \times \mathrm{EF} \times \mathrm{ED} \times \mathrm{CF}$ & $\mathrm{C} \times \mathrm{InhR} \times \mathrm{EF} \times \mathrm{ED}$ & $\mathrm{C} \times \mathrm{SA} \times \mathrm{ABS} \times \mathrm{AF} \times \mathrm{EF} \times \mathrm{ED} \times \mathrm{CF}$ & {$[30]$} \\
\hline $\mathrm{BW} \times \mathrm{AT}$ & $\mathrm{PEF} \times \mathrm{BW} \times \mathrm{AT}$ & $\mathrm{BW} \times \mathrm{AT}$ & \\
\hline
\end{tabular}

Table 3: Factors used for estimation of CADD for cancer and non-cancer risk

\begin{tabular}{|c|c|c|c|c|c|c|c|}
\hline \multirow[t]{3}{*}{ Factors } & \multirow{3}{*}{$\begin{array}{l}\text { Symb } \\
\text { ol }\end{array}$} & \multirow[t]{3}{*}{ Unit } & \multicolumn{4}{|l|}{ Value } & \multirow[t]{3}{*}{ Reference } \\
\hline & & & \multirow[t]{2}{*}{ Adult } & \multirow[t]{2}{*}{ Child } & \multicolumn{2}{|l|}{ Worker } & \\
\hline & & & & & Outdoor & Indoor & \\
\hline Soil Ingestion rate & IngR & mg/day & 100 & 200 & 100 & 50 & [31] \\
\hline Exposure Duration & ED & Year & 24 & 6 & 25 & 25 & [31] \\
\hline Exposure Frequency & $\mathrm{EF}$ & day/year & 350 & 350 & 305 & 305 & [31], [32] \\
\hline Average body weight & BW & $\mathrm{Kg}$ & 63 & 14 & 63 & 63 & {$[33],[34]$} \\
\hline Average time for non-cancer risk & $\mathrm{AT}^{*}$ & Days & 8760 & 2190 & 25550 & 25550 & [31] \\
\hline Average time for cancer risk & $\mathrm{AT}^{*}$ & Days & 24258 & 24258 & 24258 & 24258 & [31] \\
\hline Conversion Factor & $\mathrm{CF}$ & $\mathrm{Kg} / \mathrm{mg}$ & $1 \times 10^{-6}$ & $1 \times 10^{-6}$ & $1 \times 10^{-6}$ & $1 \times 10^{-6}$ & [31] \\
\hline Surface area of the skin that contact the soil & SA & $\mathrm{cm}^{2} /$ event & 5700 & 2800 & 3300 & 3300 & [31] \\
\hline Skin adherence factor & $\mathrm{AF}_{\text {soil }}$ & $\mathrm{mg} / \mathrm{cm}^{2}$ & 0.07 & 0.2 & 0.2 & NA & [31] \\
\hline Dermal absorption factor for NCR & $\mathrm{ABS}$ & $\mathrm{mg} / \mathrm{cm}^{2}$ & 0.001 & 0.001 & 0.001 & 0.001 & {$[35]$} \\
\hline
\end{tabular}

DOI: $10.9790 / 2402-1105027883$

www.iosrjournals.org

79 | Page 
Health Risk Assessment of Heavy Metal Contaminated Sites in India

\begin{tabular}{|l|l|l|l|l|l|l|l|}
\hline Dermal absorption factor for CR & ABS & $\mathrm{mg} / \mathrm{cm}^{2}$ & 0.03 & 0.03 & 0.03 & 0.03 & {$[35]$} \\
\hline Inhalation factor & InhR & $\mathrm{m}^{3} / \mathrm{day}$ & 20 & 20 & 20 & 20 & {$[31]$} \\
\hline Particle emission factor & PEF & $\mathrm{m}^{3} / \mathrm{day}$ & $1.36 \times 10^{9}$ & $1.36 \times 10^{9}$ & $1.36 \times 10^{9}$ & $\begin{array}{l}1.36 \times 1 \\
09\end{array}$ & {$[31]$} \\
\hline Life Time (ED for cancer risk) & & & & & & & \\
\hline
\end{tabular}

\section{Risk Assessment}

Main Components of risk assessment are hazard identification, dose response assessment and exposure assessment. Hazard identification is referred to the potential harm caused by contaminant to the human and/or environmental health. A dose-response relationship describes how the likelihood and severity of adverse health effects are related to the amount and condition of exposure to a receptor [31]. Exposure assessment is the determination or estimation of the magnitude, frequency, duration and route of exposure [30]. Human health risk is calculated in the term of non-carcinogenic risk (as Hazard Index) and carcinogenic risk.

Health risk analysis was done on the basis of minimum, maximum and mean concentration of contaminants for the each of the receptors (adult, child and industrial worker). Exposure of contaminant to the human can occur by any one or more of the following pathways: (a) soil ingestion (b) inhalation of dust particles (c) dermal absorption. In this study, risk assessment of heavy metals on all the receptors by all these three pathways is discussed. Analysis was made for the chronic exposure duration. In case of humans, chronic exposure duration varies from 7 years to lifetime.

Non Carcinogenic health risk is measured in terms of chronic Hazard Quotient (HQ), which is calculated as (equation 1):

$$
H Q=\frac{C A D D}{R f D}
$$

Where, CADD- Chronic Average Daily Demand and RfD- Reference Dose.

Formulas used for calculating CADD are give in table 2 and the factors used for the estimation of CADD are illustrated in table 3.

Reference Dose indicates that below that concentration, there will be no harm to even most sensitive receptor. If the HQ exceeds the unity, then site is considered to be associated with non-cancer health risk. For more than one contaminant, HQs are added to get Hazard Index (HI). (Eqn. 2)

$$
H I=\sum_{i=1}^{n} \sum_{j=1}^{n} H Q
$$

Carcinogenic Risk is estimated for the lifetime exposure and calculated by multiplying Lifetime Average Daily Dose (LADD) to Cancer Slope Factor (CSF). (Eqn. 3)

Risk $=L A D D \times C S F$......

This linear equation of carcinogenic risk estimation is valid only at risk level below 0.01 . For the risk more than 0.01 , the one hit equation is used (Eqn. 4):

$$
\text { Risk }=1-e^{-L A D D x C S F}
$$

Total carcinogenic Risk is estimated as (Eqn. 5)-

$$
\text { Cancer Risk }=\sum_{i=1}^{n} \sum_{i=1}^{n} \text { Risk }
$$

If the cancer risk value exceeds the $1 \times 10^{-6}$ than it may cause potential cancer risk to human.

\section{Results And Discussion}

By using the concentrations given in table 3 non-carcinogenic risk (HI) and carcinogenic risk are evaluated for all the three sites. Table 4 shows HI values for all the receptors based on mean and maximum concentrations for site 1. It shows that site is associated with high potential non-carcinogenic health risks. Table 5 shows HI values through different pathways based on mean concentrations for site 1. It shows that risk is associated mainly due to ingestion pathway. Table 6 shows carcinogenic health risks for all the receptors based on mean and maximum concentrations for site 1. It shows that site 1 is associated with the high carcinogenic risk to each of the receptors as the risk value exceeds the safe value of $1 \times 10^{-6}$. Table 7 shows cancer risk through different pathways based on mean concentrations for site 1. It also shows that risk is highest through ingestion and minimum through inhalation. HI values of $\mathrm{Cr}$ were observed 10.869 and 1.389 for child and adult, respectively based on maximum concentration and 1.7855 for child as per mean value. HI values of $\mathrm{Pb}$ for child were 3.5496 and 50.229 based on mean and maximum concentrations, respectively and 5.86 for industrial worker based on maximum concentration. HI of $\mathrm{Zr}$ for child, 
adult and industrial worker were 110.81, 12.3 and 12.86 based on mean concentration and 194.59, 21.6 and 29.935 based on maximum concentration. Hence more attention must be paid to $\mathrm{Cr}, \mathrm{Pb}$ and $\mathrm{Zr}$. Table 8 shows $\mathrm{HI}$ values for all the receptors based on mean and maximum concentrations for site 2. It shows HI for Child as 1.32 and 3.56 based on mean and maximum concentrations respectively, hence it is stated that site may cause potential noncarcinogenic health risk to child. Table 9 shows HI values through different pathways based on mean concentrations for site 2. It shows that risk is associated mainly due to ingestion pathway. Table 10 shows carcinogenic health risks for all the receptors based on mean and maximum concentrations for site 2. It shows that site 2 is associated with significant carcinogenic risk to each of the receptors as the risk value exceeds the safe value of $1 \times 10^{-6}$. Table 11 shows cancer risk through different pathways based on mean concentrations for site 2 . It also shows that risk is highest through ingestion and minimum through inhalation. $\mathrm{HI}$ of $\mathrm{Cr}, \mathrm{Pb}$ and $\mathrm{V}$ for child were found to be 1.52, 1.154 and 1.024 , respectively based on maximum concentration.

Table 4: Non- Carcinogenic risk to different receptors for site 1

\begin{tabular}{|l|l|l|}
\hline \multirow{2}{*}{ Receptors } & HI \\
\cline { 2 - 3 } & Based on mean concentration & Based on maximum concentration \\
\hline Adult & 12.63 & 23.86 \\
\hline Child & 116.61 & 257.096 \\
\hline Industrial Worker & 13.546 & 29.935 \\
\hline
\end{tabular}

Table 5: Non-Carcinogenic risk through different pathways for site 1

\begin{tabular}{|l|l|l|l|}
\hline \multirow{2}{*}{ Receptors } & HI (Based on mean concentration) & \multicolumn{2}{|l|}{} \\
\cline { 2 - 4 } & Ingestion & Inhalation & Dermal contact \\
\hline Child & 116.4983809 & 0.00402636 & 0.108514116 \\
\hline Adult & 12.58979226 & 0.00089297 & 0.049155275 \\
\hline Industrial Worker & 13.52061501 & 0.000777 & 0.02478 \\
\hline
\end{tabular}

Table 6: Total carcinogenic risk to different receptors for site 1

\begin{tabular}{|l|l|l|}
\hline \multirow{2}{*}{ Receptors } & Cancer Risk \\
\cline { 2 - 3 } & Based on mean concentration & Based on maximum concentration \\
\hline Adult & $295.9 \times 10^{-6}$ & $1896 \times 10^{-6}$ \\
\hline Child & $2655 \times 10^{-6}$ & $16893 \times 10^{-6}$ \\
\hline Industrial Worker & $308.5 \times 10^{-6}$ & $1976 \times 10^{-6}$ \\
\hline
\end{tabular}

Table 7: Carcinogenic risk through different pathways for site 1

\begin{tabular}{|l|l|l|l|}
\hline \multirow{2}{*}{ Receptors } & \multicolumn{3}{|l|}{ Cancer Risk (Based on mean concentration) } \\
\cline { 2 - 4 } & Ingestion & Inhalation & Dermal contact \\
\hline Child & $2652.9 \times 10^{-6}$ & $0.19 \times 10^{-6}$ & $2.59 \times 10^{-6}$ \\
\hline Adult & $294.7 \times 10^{-6}$ & $0.043 \times 10^{-6}$ & $1.17 \times 10^{-6}$ \\
\hline Industrial Worker & $307.9 \times 10^{-6}$ & $0.0377 \times 10^{-6}$ & $0.59 \times 10^{-6}$ \\
\hline
\end{tabular}

Table 8: Non- carcinogenic risk to different receptors for site 2

\begin{tabular}{|l|l|l|}
\hline \multirow{2}{*}{ Receptors } & HI \\
\cline { 2 - 3 } & Based on mean concentration & Based on maximum concentration \\
\hline Adult & 0.159 & 0.418 \\
\hline Child & 1.32 & 3.56 \\
\hline Industrial Worker & 0.0835 & 0.3067 \\
\hline
\end{tabular}

Table 9: Non-carcinogenic risk through different pathways for site 2

\begin{tabular}{|l|l|l|l|}
\hline \multirow{2}{*}{ Receptors } & \multicolumn{2}{|l|}{ HI (Based on mean concentration) } \\
\cline { 2 - 4 } & Ingestion & Inhalation & Dermal contact \\
\hline Child & 1.282074641 & 0.001583407 & 0.036768807 \\
\hline Adult & 0.142431942 & 0.000351171 & 0.016655721 \\
\hline Industrial Worker & 0.0749559 & 0.00018656 & 0.008396 \\
\hline
\end{tabular}

Table 10: Total carcinogenic risk to different receptors for site 2

\begin{tabular}{|l|l|l|}
\hline \multirow{2}{*}{ Receptors } & Cancer Risk & \multicolumn{2}{|l|}{} \\
\cline { 2 - 3 } & Based on mean concentration & Based on max concentration \\
\hline Adult & $119 \times 10^{-6}$ & $187 \times 10^{-6}$ \\
\hline Child & $1068 \times 10^{-6}$ & $1679 \times 10^{-6}$ \\
\hline Industrial Worker & $124 \times 10^{-6}$ & $1068 \times 10^{-6}$ \\
\hline
\end{tabular}


Health Risk Assessment of Heavy Metal Contaminated Sites in India

Table 11: Carcinogenic risk through different pathways for site 2

\begin{tabular}{|l|l|l|l|}
\hline \multirow{2}{*}{ Receptors } & \multicolumn{2}{|l|}{ Cancer Risk (Based on mean Concentration) } & Dermal Contact \\
\cline { 2 - 4 } & Ingestion & Inhalation & $1.043 \times 10^{-6}$ \\
\hline Child & $1067.023 \times 10^{-6}$ & $0.0786 \times 10^{-6}$ & $0.47 \times 10^{-6}$ \\
\hline Adult & $118.54 \times 10^{-6}$ & $0.01744 \times 10^{-6}$ & $0.238 \times 10^{-6}$ \\
\hline Industrial Worker & $123.8 \times 10^{-6}$ & $0.01518 \times 10^{-6}$ & \\
\hline
\end{tabular}

Table 12: Non- carcinogenic risk to different receptors for site 3

\begin{tabular}{|l|l|l|}
\hline \multirow{2}{*}{ Receptors } & HI \\
\cline { 2 - 3 } & Based on mean concentration & Based on max concentration \\
\hline Adult & 0.253 & 0.358 \\
\hline Child & 2.1429 & 3.0038 \\
\hline Industrial Worker & 0.25 & 0.3567 \\
\hline
\end{tabular}

Table 13: Non-carcinogenic risk through different pathways for site 3

\begin{tabular}{|l|l|l|l|}
\hline \multirow{2}{*}{ Receptors } & HI (Based on mean concentration) & Dermal contact \\
\cline { 2 - 4 } & Ingestion & Inhalation & 0.045402475 \\
\hline Child & 2.095547665 & 0.001993191 & 0.020566643 \\
\hline Adult & 0.232804638 & 0.000442054 & 0.010368 \\
\hline Industrial Worker & 0.243205897 & 0.000385 & \\
\hline
\end{tabular}

Table 14: Carcinogenic risk to different receptors for site 3

\begin{tabular}{|l|l|l|}
\hline \multirow{2}{*}{ Receptors } & Cancer Risk & Based on maximum concentration \\
\cline { 2 - 3 } & Based on mean concentration & $233.3 \times 10^{-6}$ \\
\hline Adult & $150.39 \times 10^{-6}$ & $2092.8 \times 10^{-6}$ \\
\hline Child & $1349.48 \times 10^{-6}$ & $243.1 \times 10^{-6}$ \\
\hline Industrial Worker & $156.7 \times 10^{-6}$ & \\
\hline
\end{tabular}

Table 15: Carcinogenic risk through different pathways for site 3

\begin{tabular}{|l|l|l|l|}
\hline \multirow{2}{*}{ Receptors } & Cancer Risk (Based on mean concentration) & Dermal Contact \\
\cline { 2 - 4 } & Ingestion & Inhalation & $1.31 \times 10^{-6}$ \\
\hline Child & $1348.08 \times 10^{-6}$ & $0.09 \times 10^{-6}$ & $0.59 \times 10^{-6}$ \\
\hline Adult & $149.7 \times 10^{-6}$ & $0.022 \times 10^{-6}$ & $0.3 \times 10^{-6}$ \\
\hline Industrial Worker & $156.45 \times 10^{-6}$ & $0.019 \times 10^{-6}$ & \\
\hline
\end{tabular}

Table 12 shows $\mathrm{HI}$ values for all the receptors based on mean and maximum concentrations for site 3 . It shows that site 3 is associated with non-carcinogenic health risks only for child. Table 13 shows HI values through different pathways based on mean concentrations for site 3. It shows that risk is associated mainly due to ingestion pathway. Table 14 shows carcinogenic health risks for all the receptors based on mean and maximum concentrations for site 3. It shows that site 3 is associated with the high carcinogenic risk to each of the receptors as the risk value exceeds the safe value of $1 \times 10^{-6}$. Table 15 shows cancer risk through different pathways based on mean concentrations for site 3. It also shows that risk is highest through ingestion and minimum through inhalation. Site has only $\mathrm{Cr}$ causing potential carcinogenic risks to all the receptors.

\section{Conclusion}

Three contaminated sites from different parts of India were selected and health risk assessment was done in order to determine the associated health risks of contaminants present at these sites. Results of the previous work on the concentration of heavy metals at these sites done by various researchers were adopted for risk assessment. Results suggest that site 1 (i.e., Balanagar industrial area) has highest potential for carcinogenic and noncarcinogenic diseases in all the receptors. Site 2 (Pali Industrial Area) and site 3 (Surat Industrial Area) have noncarcinogenic risk only for children. But both sites have significant carcinogenic risk for all the receptors. Children are found to be most susceptible to carcinogenic and non carcinogenic diseases as compared to adult and industrial worker. Ingestion is found to be major pathway for both the diseases in all cases. Children are subjected to cancer risks due to dermal contact also. But inhalation does not cause any significant risk in any of the cases.

At site 1, mainly $\mathrm{Cr}, \mathrm{Pb}$ and $\mathrm{Zr}$ are responsible for the non-carcinogenic health risks to the receptors. $\mathrm{Cr}$ and $\mathrm{Pb}$ are also carcinogens, hence causing carcinogenic health risks at site 1 . Hence more attention must be given to remove $\mathrm{Cr}, \mathrm{Pb}$ and $\mathrm{Zr}$ from the site during the remediation process. Site 2 has $\mathrm{Cr}, \mathrm{Pb}$ and $\mathrm{V}$ which are the main cause of potential non-carcinogenic health risks to children. $\mathrm{Cr}$ and $\mathrm{Pb}$ are also responsible for carcinogenic health risks to receptors. Site 3 has mainly $\mathrm{Cr}$ which cannot be avoidable as it causes carcinogenic health risks to human. Hence, remediation process must be selected keeping in view future land use and health risk to remove all these heavy metals to acceptable limits. Priority should be given to site 1 as it has highest values of $\mathrm{HI}$ and carcinogenic risks. 


\section{References}

[1]. MoEF Report (2013). "Existing data and general information on contaminated site in India," Inventory and mapping of probably contaminated sites in India.

[2]. $\quad$ Fosmire GJ (1990), "Zinc Toxicity”, Am. J. Clin. Nutr. 51(2): 225 -227.

[3]. Nolan K., (2003), “Copper Toxicity Syndrome”, J. Orthomol. Psychiatry 12(4): 270 - 282.

[4]. Young R. A., (2005), "Toxicity Profiles: Toxicity Summary for Cadmium, Risk Assessment Information System, RAIS”, University of Tennessee (rais.ornl.gov/tox/profiles/cadmium.shtml).

[5]. Duruibe, J. O., Ogwuegbu, M. O. C. and Egwurugwu, J. N. (2007), "Heavy metal pollution and human biotoxic effects", International Journal of Physical Sciences Vol. 2 (5), pp-112-118.

[6]. RTI, (2012), "Toxicological Profile for Chromium", U.S. Department of Health and Human Services, Agency for Toxic Substances and Disease Registry, Atlanta.

[7]. European Union (2002). Heavy Metals in Wastes, European Commission on Environment (http://ec.europa.eu/environment/waste/studies/pdf/heavy_metals report.pdf)

[8]. Ogwuegbu M. O. C. and Muhanga W., (2005). "Investigation of Lead Concentration in the Blood of People in the Copperbelt Province of Zambia", J. Environ. (1): $66-75$.

[9]. Jarup L. (2003) "Hazards of heavy metal contamination" Oxford Journals Medicine \& Health Vol 68:167-182.

[10]. Patel K. S., Shrivas K., Hoffmann P. and Jakubowski N., (2006) "A survey of lead pollution in Chhattisgarh State, central India" Environmental Geochemistry and Health 28:11-17.

[11]. Govil P. K., Sorlie J. E, Murthy N. N. , Sujatha D., Reddy G. L. N., Rudolph-Lund Kim, Krishna A. K. and Mohan K.R. (2008), "Soil contamination of heavy metals in the Katedan Industrial Development Area, Hyderabad, India" Environ Monit Assess 140:313-323.

[12]. Machender G., Dhakate R., Prasanna L. and Govil P.K., (2010) "Assessment of heavy metal contamination in soils around Balanagar industrial area, Hyderabad India", Environmental Earth Science DOI 10.1007/s12665-010-0763-4.

[13]. Sinha S., Gupta A. K., Bhatt K., Pandey K., Rai U. N. and Singh K. P. (2006). “ Distribution of metal in the edible plant grow at Jajmau, Kanpur (India) receiving treated tannery wastewater: relation with physico-chemical properties of the soil”. Environmental Monitoring and Assessment, Springer, Vol 115, Issue 1, pp 1-22.

[14]. Rawat M., Ramanathan A. L. and Subramanian V., (2009). "Quantification and distribution of heavy metals from small scale industrial areas of Kanpur city, India”. Journal of hazardous materials, Vol. 172, Issues 2-3, pp 1145-1149 .

[15]. $\quad$ Singh R. K., Sengupta B., Bali R., Shukla B. P., Gurunadharao V. V. S., and Srivatstava R (2009). "Identification and mapping of chromium (VI) plume in groundwater for remediation: A case study at Kanpur, Uttar Pradesh". Journal of the Geological Society of India, Vol.74, Issue 1,Springer, pp 49-57.

[16]. Gowd S.S., Reddy M.R., and Govil P.K., (2010) “Assessment of heavy metal contaminated soil at Jajmau (Kanpur) and Unnao industrial areas of the Ganga Plain, Uttar Pradesh, India" Journal of hazardous materials 174, 113-121.

[17]. Bhatnagar M. K., Singh R., Gupta S., Prachi B. (2013) "Study of tannery effluents and its effects on sediments of river Ganga in special refrence to heavy metals at Jajmau, Kanpur, India" Journal of Environmental Research and Development vol. 8 no. 1

[18]. Krishna A. K. and Govil P. K. (2005) "Heavy metal distribution and contaminationin soils of Thane-Belapur industrial development area, Mumbai, Western India", Environ. Geol. 47: 1054-1061.

[19]. Fazeli M., Khosravan F., Hossini M., Sathyanaryan S., Satish P. N., (1998) "Enrichment of heavy metals in paddy crops irrigated by paper mill effluents near Nanjangud, Mysore Distict, Karnatake, India" Environmental Geology 34 (4)

[20]. Shivakumar D., Srikantaswamy S., Sreenivasa S. and Kiran B. D., (2012) "Speciation and Geochemical Behaviour of Heavy Metals in Industrial Area Soil of Mysore City, India" Journal of Environmental Protection, 3, 1384-1392

[21]. Govil P. K., Reddy G.L.N., and Krishna A.K., (2001) "Contamination of soil due to heavy metals in the Patancheru industrial development area, Andhra Pradesh, India" Environmental Geology 41:461-469.

[22]. Reddy V. M., Satpathy D. and Dhiviya K. S., (2013) “Assessment of heavy metals $(\mathrm{Cd}$ and $\mathrm{Pb})$ and micronutrients $(\mathrm{Cu}, \mathrm{Mn}$, and $\mathrm{Zn})$ of Paddy(Oryza sativa L.) field surface soil and water in a predominantly paddy-cultivated area at Puducherry (Pondicherry, India), and effects of the agricultural runoff on the elemental concentrations of a receiving rivulet" Environ Monit Assess 185:6693-6704.

[23]. Krishna A. K. and Govil P. K. (2004) "Heavy metal contamination of soil around Pali Industrial Area, Rajasthan, India" Environmental Geology 47: 38-44.

[24]. Dantu S. (2009) "Heavy metals concentration in soils of southeastern part of Ranga Reddy district, Andhra Pradesh, India" Environ Monit Assess 149:213-222.

[25]. Krishna A. K. and Govil P. K. (2007) "Soil contamination due to heavy metals from an industrial area of Surat, Gujarat, Western India" Environ Monit Assess 124:263-275.

[26]. Nath T.N.,(2013) "Heavy metals contamination of tea estates soil in Sivasagar and Dibrugarh districts of Asam, India" International journal of Advancements in Research \& Technology, Volume 2, Issue 4.

[27]. Dheeba B., and Sampathkumar P.(2012) "Evaluation of Heavy Metal Contamination in Surface Soil around Industrial Area, Tamil Nadu, India" International Journal of ChemTech Research ISSN:0974-4290.

[28]. Bhagure G.R., and Mirgane S.R. (2011) "Heavy metal concentration in ground waters and soils of Thane Region of Maharashtra, India" Environ Monit Assess 173:643-652.

[29]. Singh A., Sharma R. K., Agrawal M. and Marshall F. M., (2010) "Risk assessment of heavy metal toxicity through contaminated vegetables from waste water irrigated area of Varanasi, India" Tropical Ecology 51(2S):375-387.

[30]. USEPA, (1989), Risk Assessment Guidance for Superfund Volume I Human Health Evaluation Manual (Part A) Interim Final, Washington, D.C.

[31]. USEPA, (2002). "Supplemental guidance for developing soil screening levels for superfund sites", OSWER 9355.Office of Emergency and Remedial response, Washington, DC, pp 4-24.Factories Act, (1948)

[32]. ICMR, (2000), "Nutrient requirements and recommended dietary allowance for Indians".

[33]. Shome S., Roy P., Pal M. and Bharati P., (2014) "Variation of Adult Height and Weights in India: State \& Zonewise Analysis" Human Biology Journal ISSN 22774424 USEPA (2011). "Exposure Factors Handbook".

[34]. World Bank, "Life expectancy at birth", http://data.worldbank.org/indicator/SP.DYN.LE00.IN.

[35]. Goel S. (2006) "Health Risk Assessment for a contaminated Site: A case Study" Pract. Period. Hazard. Toxic Radioact. Waste Manage. 10:216-225.

DOI: $10.9790 / 2402-1105027883$

www.iosrjournals.org

83 | Page 